\title{
Polyethylenimine-Modified Bombyx mori Silk Fibroin as a Delivery Carrier of the ING4-IL-24 Coexpression Plasmid
}

\author{
Longxing Niu, Guo Chen, Yanfei Feng, Xueping Liu, Peng Pan, Linling Huang, Ying Guo and Mingzhong Li *D \\ National Engineering Laboratory for Modern Silk, Department of Textile Engineering, College of Textile and \\ Clothing Engineering, Soochow University, Suzhou 215123, China; niu18860902006@163.com (L.N.); \\ chenguo148@126.com (G.C.); fengyanfei0123@126.com (Y.F.); 18862107248@163.com (X.L.); \\ ppanpanpeng@stu.suda.edu.cn (P.P.); hll4146@163.com (L.H.); gyguoyingy@163.com (Y.G.) \\ * Correspondence: mzli@suda.edu.cn; Tel.: +86-512-6706-1150
}

Citation: Niu, L.; Chen, G.; Feng, Y.; Liu, X.; Pan, P.; Huang, L.; Guo, Y.; Li, M. Polyethylenimine-Modified Bombyx mori Silk Fibroin as a Delivery Carrier of the ING4-IL-24 Coexpression Plasmid. Polymers 2021, 13, 3592. https://doi.org/10.3390/ polym13203592

Academic Editor: Hsiuying Wang

Received: 23 September 2021

Accepted: 14 October 2021

Published: 19 October 2021

Publisher's Note: MDPI stays neutral with regard to jurisdictional claims in published maps and institutional affiliations.

Copyright: (c) 2021 by the authors. Licensee MDPI, Basel, Switzerland. This article is an open access article distributed under the terms and conditions of the Creative Commons Attribution (CC BY) license (https:// creativecommons.org/licenses/by/ $4.0 /)$.

\begin{abstract}
One of the major challenges for lung cancer gene therapy is to find a gene delivery vector with high efficiency and low toxicity. In this study, low-molecular-weight polyethyleneimine (PEI, $1.8 \mathrm{kDa}$ ) was grafted onto the side chains of Bombyx mori silk fibroin (BSF) to prepare cationized BSF (CBSF), which was used to package the plasmid DNA (pDNA) encoded by the inhibitor of growth 4 (ING4) and interleukin-24 (IL-24). FTIR and ${ }^{1} \mathrm{H}-\mathrm{NMR}$ spectra demonstrated that PEI was effectively coupled to the side chains of BSF by amino bonds. The results of the trinitrobenzene sulfonic acid method and zeta potential showed that the free amino group content on BSF increased from $125.1 \pm 1.2 \mu \mathrm{mol} / \mathrm{mL}$ to $153.5 \pm 2.2 \mu \mathrm{mol} / \mathrm{mL}$, the isoelectric point increased from 3.68 to 8.82 , and the zeta potential reversed from $-11.8 \pm 0.1 \mathrm{mV}$ to $+12.4 \pm 0.3 \mathrm{mV}$ after PEI grafting. Positively charged CBSF could package pDNA to form spherical CBSF/pDNA complexes. In vitro, human lung adenocarcinoma A549 cells and human embryonic lung fibroblast WI-38 cells were transfected with CBSF/pDNA complexes. Confocal laser scanning microscopy analysis and flow cytometry tests showed that CBSF/pDNA complexes can effectively transfect A549 cells, and the transfection efficiency was higher than that of $25 \mathrm{kDa}$ PEI/pDNA complexes. CCK-8 assay results showed that CBSF/pDNA complexes significantly inhibited the proliferation of A549 cells but had no significant effect on WI-38 cells and exhibited lower cytotoxicity to WI-38 cells than $25 \mathrm{kDa}$ PEI. Therefore, a gene delivery system, constructed with the low-molecular-weight PEI-modified silk fibroin protein and the ING4-IL-24 double gene coexpression plasmid has potential applications in gene therapy for lung cancer.
\end{abstract}

Keywords: silk fibroin; gene carrier; lung cancer; inhibitor of growth 4; interleukin-24

\section{Introduction}

Lung cancer has become a leading cause of cancer-related deaths worldwide due to its high incidence, strong aggressiveness, late diagnosis, and lack of effective treatments [1]. Chemotherapy, surgical resection, and radiotherapy can be used to treat lung cancer, but these therapies have limited efficacy in treating advanced cancer and drug-resistant tumors [2]. Gene therapy involves using oligonucleotides to specifically target and regulate the abnormal genetic expression related to cancer development to cancer cells, which can significantly reduce the systemic cytotoxicity of cancer patients, so gene therapy was considered to be an efficient and promising cancer treatment method [3]. One of the key challenges for lung cancer gene therapy is to find therapeutic genes with remarkable curative effects and gene delivery carriers with high efficiency and low toxicity.

Growth inhibitory factor inhibitor of growth 4 (ING4), as an intracellular tumor growth inhibitory factor, can significantly inhibit the growth of tumor cells inducing cell cycle changes and cell apoptosis [4]. ING4 can inhibit the transcriptional activity of nuclear factor NF- $\mathrm{KB}$ and hypoxia-inducible factor HIF-1 $\alpha$ to inhibit tumor angiogenesis, which has been revealed to have a suppressive role in various cancers, such as lung cancer, hepatocellular 
carcinoma, glioma, breast cancer, colon cancer, and ovarian carcinoma [5,6]. Interleukin-24 (IL-24) is a membrane receptor-mediated tumor growth inhibitory factor that inhibits the expression of the transcription factor GLI1 in lung cancer cells by inhibiting the Akt-mTOR and SDF-1/CXCR4 signaling axes, thereby inducing DNA damage in lung cancer cells and leading to cell death [7]. IL-24 can also indirectly inhibit angiogenesis by inhibiting the expression of PI3K/Akt signal, vascular endothelial growth factor VEGF, and transforming growth factor TGF-TGF, which play important roles in angiogenesis of lung cancer cells [8]. In addition, IL-24 shows special antitumor activity and can kill nearby tumor cells without toxicity to normal cells. Tumor cells often contain multiple genetic abnormalities, which limit the efficacy of a single gene-mediated cancer therapy [9]. The coexpression of the ING4 and IL-24 double genes can selectively inhibit tumor angiogenesis and the growth of tumor cells through pathways both inside and outside of the cells.

Another major challenge for lung cancer gene therapy is to find a gene delivery vector with high efficiency and low toxicity. Gene delivery vectors include viral vectors and nonviral vectors. Viral vectors have the advantage of high transfection efficiency, but they have the potential risk of carcinogenicity and immunogenicity [10]. In contrast, non-viral vectors, such as polyethylenimine (PEI), polylysine, cationic lipidosomes, and polysaccharides, have the advantages of having a large DNA delivery capacity and low immunogenicity [11]. High-molecular-weight polyethylenimine $(25 \mathrm{kDa})$ is the "gold" standard for non-viral vectors due to its high transfection efficiency in different cell lines, but it shows significant cytotoxicity at the initial stage of treatment [12]. In contrast, low-molecular-weight PEI $(1.8 \mathrm{kDa})$ shows lower cytotoxicity. However, the transfection efficiency is lower than that of high-molecular-weight PEI [13]. In order to improve the transfection efficiency of low-molecular-weight PEI, a variety of methods are used to modify PEI. For example, PEI conjugated with silica remarkably enhanced EGFP-N1 gene expression in murine neuroblastoma cells up to 38 fold compared to PEI $25 \mathrm{kDa}$ [14]. However, their safety is still a severe challenge for in vivo applications because they are nondegradable. Biodegradable polymers, such as polyethylene glycol [15], polylactic acid [16], gelatin [17], and hyaluronic acid [18], are also used to modify PEI to minimize its cytotoxicity. However, polyethylene glycol and polylactic acid shield the positive charge of PEI, resulting in a decrease in transfection efficiency [19]. Gelatin and hyaluronic acid lack sufficient mechanical strength, and the fast degradation rate can easily lead to the rapid release of the target gene [20,21]. It is necessary to find biodegradable polymers to modify PEI in order to prepare gene carriers that can stably encapsulate the target gene, improve transfection efficiency, and reduce cytotoxicity.

Silk fibroin from Bombyx mori has been used as a tissue engineering scaffold and a delivery vehicle for biologically active molecules because of its unique combination of biocompatibility, controllable biodegradability, and mechanical stability [22,23]. When silk fibroin is used as a gene carrier, not only can the structural hierarchy, composition, and crystallinity be modified to achieve the designed release behavior without affecting the release of the target gene, but it also shows resistance capacity to DNA enzymes [24]. It can also protect DNA from potentially unstable conditions such as temperature and ultraviolet radiation [25]. In addition, silk fibroin can be modified through the carboxyl group of glutamic acid and aspartic acid, the phenolic hydroxyl group of tyrosine and the amino group of arginine, which improve the application of silk fibroin as a gene carrier [26]. In our previous study, we used spermine to modify Bombyx mori silk fibroin (BSF) [27]. Coating PEI/pDNA complexes with modified silk fibroin not only effectively shields the excessive positive charge on the surface of the PEI/pDNA complexes but also shows lower cytotoxicity and higher transfection efficiency than the PEI/pDNA complexes. BSF showed great potential as a gene delivery carrier.

In this study, BSF modified with low-molecular-weight PEI is used to encapsulate ING4 and IL-24 double gene coexpression plasmids to establish a high-efficiency and lowtoxicity gene delivery carrier against lung cancer cells. We hypothesized that PEI can be grafted onto the side chains of BSF and that cationized Bombyx mori silk fibroin (CBSF) can 
be obtained. The positively charged silk fibroin can effectively package the ING4-IL-24 double gene coexpression plasmid pDNA to obtain CBSF/pDNA complexes. The complexes not only overcome the shortcomings of high-molecular-weight PEI with strong side effects but can also effectively transfect lung cancer cells and inhibit the growth of lung cancer cells and have no obvious cytotoxicity to normal cells. Based on this hypothesis, the carboxyl group of silk fibroin was activated first by using 1-ethyl-3- (3-dimethylaminopropyl) carbodiimide hydrochloride (EDC) to couple with the amino group of PEI to form CBSF. The zeta potential, trinitrobenzene sulfonic acid (TNBS), isoelectric points (pI), Fourier transform infrared (FTIR), and nuclear magnetism $\left({ }^{1} \mathrm{H}-\mathrm{NMR}\right)$ were used to characterize CBSF. Then, based on the electrostatic interaction, CBSF could wrap and compress pDNA to form CBSF/pDNA complexes. Agarose gel electrophoresis was used to detect the ability of CBSF to package pDNA. Zeta potential and scanning electron microscopy (SEM) were used to characterize the surface charge, particle size, and morphology of the composite. Finally, the CBSF/pDNA complexes were transfected into human embryonic lung adenocarcinoma cells A549 and human embryonic lung fibroblasts WI-38 in vitro. Confocal laser scanning microscopy (CLSM) observed the cell morphology and transfection effect. The cell counting kit-8 (CCK-8) method detected the effect of the complexes on cell proliferation and flow cytometry detected the cell transfection efficiency.

\section{Materials and Methods}

\subsection{Preparation of Silk Fibroin Solution}

Bombyx mori raw silks were degummed following a previously described procedure [28]. Briefly, the silk fibers (Nantong, China) were boiled three times in $0.05 \mathrm{wt} \%$ $\mathrm{Na}_{2} \mathrm{CO}_{3}$ aqueous solution for $30 \mathrm{~min}$ to remove sericin and dried at $60^{\circ} \mathrm{C}$ after thorough rinsing with distilled water for subsequent experiments. The extracted fibers were dissolved in a ternary solvent system composed of calcium chloride, ethanol, and water (1:2:8 molar ratio) at $70 \pm 2{ }^{\circ} \mathrm{C}$ for $1 \mathrm{~h}$. After being completely cooled, the mixed solution was dialyzed (MWCO, 8-14 $\mathrm{kDa}$ ) in deionized water for 3 days to obtain the regenerated BSF solution. The BSF solution was centrifuged (Heraeus PICO17, Thermo Scientific Company, Germany) at 10,000 rpm for $5 \mathrm{~min}$ and then stored in a $4{ }^{\circ} \mathrm{C}$ refrigerator.

\subsection{Preparation of Cationized Silk Fibroin Solution}

Fifty milliliters of the BSF solution $(1.0 \mathrm{wt} \%)$ was cooled to $0 \sim 2{ }^{\circ} \mathrm{C}$ in an ice bath. Then, polyethylenimine (PEI, MW $1800 \mathrm{Da}$, Sigma-Aldrich) solution, which accounted for 0.1, 0.5, $1.0,2.0,4.0,6.0,8.0$ and $10.0 \mathrm{wt} \%$ of the BSF weight in solution, was added. After adjusting the $\mathrm{pH}$ value to 7.2 7.5 with 0.1 M 2-(N-morpholino)ethanesulfonic acid (MES, SigmaAldrich) solution, N-hydroxysuccinimide (NHS, Sigma-Aldrich) was added to the mixture to account for $10 \mathrm{wt} \%$ of the weight of BSF in solution. After the $\mathrm{pH}$ value was stabilized, the $\mathrm{pH}$ of solution was adjusted to $5.0 \sim 6.0$ by adding $0.1 \mathrm{M}$ MES solution. Then, 1-ethyl-3(3-dimethylaminopropyl) carbodiimide hydrochloride (EDC, Sigma-Aldrich) accounting for $20 \mathrm{wt} \%$ of the weight of BSF in solution was added. The reaction lasted for $6 \mathrm{~h}$ in an ice bath, and finally, the solution was incubated in a $4{ }^{\circ} \mathrm{C}$ refrigerator overnight. The mixed solutions were dialyzed with deionized water for 3 days. After centrifugation at 10,000 rpm for $5 \mathrm{~min}$, the CBSF solution was obtained.

\subsection{Characterization of $C B S F$}

BSF and CBSF solutions were diluted with distilled water to $0.1 \mathrm{wt} \%$ for zeta potential measurement. To measure the potentials of the liquids, $1 \mathrm{~mL}$ sample solutions were taken and tested in a Zetasizer Nano ZS90 (Malvern Zetasizer Nano ZS90; Malvern Instruments, Malvern, UK) at $25^{\circ} \mathrm{C}$. Each group of samples was repeated three times.

To adjust the $\mathrm{pH}$ range of the solution from 3 to $10,0.1 \mathrm{M}$ hydrochloric acid and $0.1 \mathrm{M}$ sodium hydroxide were used. Then the zeta potential values of BSF and CBSF at different $\mathrm{pH}$ values were measured to determine the $\mathrm{pI}$ value. 
The content of free amino groups was determined by the trinitrobenzene sulfonic acid (TNBS) method [29]. Glycine was used as a standard. Standard solutions $(20 \mu \mathrm{mol} / \mathrm{mL}$, $1 \mathrm{~mL})$ and test samples $(0.5 \mathrm{mg} / \mathrm{mL}, 1 \mathrm{~mL})$ were prepared. Each solution was equalized at $40{ }^{\circ} \mathrm{C}$ for $30 \mathrm{~min}$ after $1 \mathrm{~mL}$ of $4.0 \mathrm{wt} \% \mathrm{NaHCO}_{3}$ buffer solution was added. Then, $1 \mathrm{~mL}$ of $0.05 \mathrm{wt} \%$ TNBS aqueous solution was added to the mixture. The reaction continued for $2 \mathrm{~h}$ at $40^{\circ} \mathrm{C}$. Finally, $1 \mathrm{~mL}$ of $1 \mathrm{M} \mathrm{HCl}$ was added. An ultraviolet spectrophotometer (UV-3600; Shimadzu, Tokyo, Japan) was used to measure the absorbance at $340 \mathrm{~nm}$. The sample absorbance readings were changed to reflect the free amino group content using a standard curve obtained with glycine.

PEI, BSF and CBSF solids were obtained by freezing the solution at $-80^{\circ} \mathrm{C}$ for $6 \mathrm{~h}$ and then freeze-drying in a Virtis Genesis 25-LE lyophilizer for $48 \mathrm{~h}$. The dry solids of PEI, BSF and CBSF were cut into tiny particles and screened with a 600 mesh sieve. Approximately $1 \mathrm{mg}$ of particles was pressed into a pellet with $200 \mathrm{mg}$ of potassium bromide. FTIR analysis was performed with a Nicolet 5700 spectrometer (Thermo Company, Madison, WI, USA). The measurements were taken in the range of $500-4000 \mathrm{~cm}^{-1}$.

Approximately $5 \mathrm{mg}$ BSF, CBSF and PEI freeze-dried powders were dissolved in $400 \mu \mathrm{L}$ of $\mathrm{D}_{2} \mathrm{O}$, respectively. The solution was then loaded into a nuclear magnetic tube and the ${ }^{1} \mathrm{H}-\mathrm{NMR}$ spectra of the samples were measured using a superconducting nuclear magnetic resonance spectrometer (Avance III HD 400 MHz, Brucker, USA).

\subsection{Construction of Recombinant Plasmids Coexpressing ING4 and IL-24 Double Genes}

The construction method of the ING4-IL-24 double-gene coexpression plasmid containing green fluorescent protein (GFP) gene has been described previously [30]. Briefly, the ING4 and IL-24 fragments were amplified by polymerase chain reaction (PCR) using the pADTRACK-CMV-ING4 or pADTRACK-CMV-IL-24 plasmid as templates and combined with specific primers for ING4 or IL-24. The ING4 and IL-24 fragments were cloned into PADTrack-CMV-polyA + promoter transfer plasmids encoding the green fluorescent protein (GFP) gene at the BGL II, Sal I, Xhol I, and Xbal I sites, respectively. Then, the ING4-IL-24 double gene coexpression plasmid was propagated in Escherichia coli DH5 $\alpha$ cells (Invitrogen, Carlsbad, CA, USA), and the ultrapure, endotoxin-free plasmid DNA was prepared using a QIA filtration kit (Qiagen, Chatsworth, CA, USA). The plasmid concentration was $100 \mathrm{ng} / \mu \mathrm{L}$, which was measured by ultraviolet absorbance (Thermo Fisher Scientific, Waltham, MA, USA).

\subsection{Preparation of $C B S F / p D N A$ and $P E I / p D N A$ Complexes}

Both CBSF and $25 \mathrm{kDa}$ PEI solutions were diluted to $1 \mu \mathrm{g} / \mu \mathrm{L}$ with deionized water. The CBSF/pDNA complex with a ratio of $4 / 2$ was obtained by adding $4 \mu \mathrm{L}$ of CBSF into a $20 \mu \mathrm{L}$ of pDNA solution and then swirling for $30 \mathrm{~min}$. The same method can also obtain $\mathrm{CBSF} / \mathrm{pDNA}$ complexes with ratios of $8 / 2,16 / 2,32 / 2,64 / 2,128 / 2,196 / 2,256 / 2$, and a $25 \mathrm{kDa} \mathrm{PEI} / \mathrm{pDNA}$ complex with the ratio of $10 / 2$.

\subsection{Gel Retardation Assay}

Agarose gel electrophoresis was used to analyze the packaging ability of CBSF and $25 \mathrm{kDa}$ PEI to pDNA. The complex suspensions were loaded onto a $1.0 \mathrm{wt} \%$ agarose gel containing ethidium bromide $(0.5 \mu \mathrm{g} / \mathrm{mL})$ and run in Tris-acetate buffer at $100 \mathrm{~V}$ for $30 \mathrm{~min}$. Finally, the results were observed by irradiation under UV light.

\subsection{Characterization of CBSF/pDNA Complexes}

The suspensions of CBSF/pDNA and PEI/pDNA complexes were tested in triplicate for particle size and surface charge using a zeta potential analyzer at $25^{\circ} \mathrm{C}$.

The composite solution was dripped on a silicon wafer. The liquid was blown dry with nitrogen and then sprayed with gold for $90 \mathrm{~s}$. The surface morphology of the composite was observed under a scanning electron microscope (SEM, Hitachi S-4800, Hitachi Ltd., Tokyo, Japan). 


\subsection{In Vitro Gene Transfection}

Human lung adenocarcinoma A549 and human embryonic lung fibroblast WI-38 were purchased from ATCC (Manassas, VA, USA). A549 and WI-38 cells were seeded on cell culture dishes (NEST, Lot No 2013008) at a density of $1 \times 10^{5}$ and cultured in Dulbecco's modified Eagle's medium (DMEM, Gibco, USA), supplemented with 10\% fetal calf serum (FBS, Gibco, USA) and $1 \%$ antibiotics (penicillin and streptomycin) at $37^{\circ} \mathrm{C}$ using a humidified $5 \% \mathrm{CO}_{2}$ incubator. Under microscopic visualization, when cells reached $85-90 \%$ confluence with normal morphology, they were washed with phosphate buffered saline (PBS) and placed in serum-free DMEM for $2 \mathrm{~h}$. Then, after the cells were washed with PBS, binary complexes containing $2 \mu \mathrm{g}$ of pDNA were diluted in $0.5 \mathrm{~mL}$ of DMEM and added dropwise to the cells. After $4 \mathrm{~h}$ of incubation, the medium was replaced by DMEM culture medium (10\% FBS and 1\% antibiotics) and continued to incubate for 24 $\mathrm{h}$. The expression of green fluorescent protein in cells was observed by laser confocal microscope (CLSM, FV1000, Olympus, Japan) at 200 times.

\subsection{Evaluation of Cell Viability}

Cell viability was carried out using the CCK-8 assay. A549 cells and WI-38 cells were seeded in 96-well plates (TCP, Corning Inc., New York, NY, USA) 24 h prior to adding the complexes. When approximately $80 \%$ confluence of cells was achieved, the cells were incubated with CBSF/pDNA complexes in fresh serum-free DMEM. After $4 \mathrm{~h}$ of incubation, the media was replaced with $200 \mu \mathrm{L}$ of DMEM culture medium (10\% FBS and $1 \%$ antibiotics $)$ for $24 \mathrm{~h}$. Then CCK-8 $(40 \mu \mathrm{L} /$ well $)$ and DMEM $(400 \mu \mathrm{L} /$ well $)$ were added to the plate, and the cells were incubated for $2 \mathrm{~h}$ at $37^{\circ} \mathrm{C}$. The absorbance was recorded at $450 \mathrm{~nm}$ by using a microplate reader (Synergy HT, BioTek Instruments, USA). Cells without incubated complexes were used as a control. Cell viability was calculated from the relation of absorbance, i.e., (Asample/Acontrol)*100 and plotted as a percentage of viability. Each experiment was performed in triplicate and repeated at least three times.

\subsection{Transfection Efficiency Evaluation}

The transfection efficiency of the complexes was measured by flow cytometry (FC500, Beckman-Coulter, USA). A549 cells were seeded at a density of $1 \times 10^{6}$ cell/well in 6-well plates. The transfected method was as described above. The cells were trypsinized, washed, and resuspended in PBS. The expression levels of GFP were determined by flow cytometry (FC500, Beckman-Coulter, USA) within $30 \mathrm{~min}$.

\subsection{Statistical Analysis}

All data are listed as means \pm standard deviation. Statistical analysis was performed using one-way analysis of variance ( $t$-test). Differences at $p<0.05$ are considered statistically significant.

\section{Results}

\subsection{Characterization of CBSF}

The synthesis principle of CBSF is shown in Figure 1. The carbon-nitrogen double bond $(-\mathrm{N}=\mathrm{C}-)$ on the water-soluble EDC can couple with the carboxyl groups of aspartic acid and glutamic acid in silk fibroin to form unstable O-isouryl urea derivatives. Subsequently, the free hydroxyl $(-\mathrm{OH})$ on the NHS reacted with the unstable derivative to form a stable intermediate product. The intermediate product further reacted with the free amino group in PEI to form a new amide bond, and finally CBSF was obtained. 


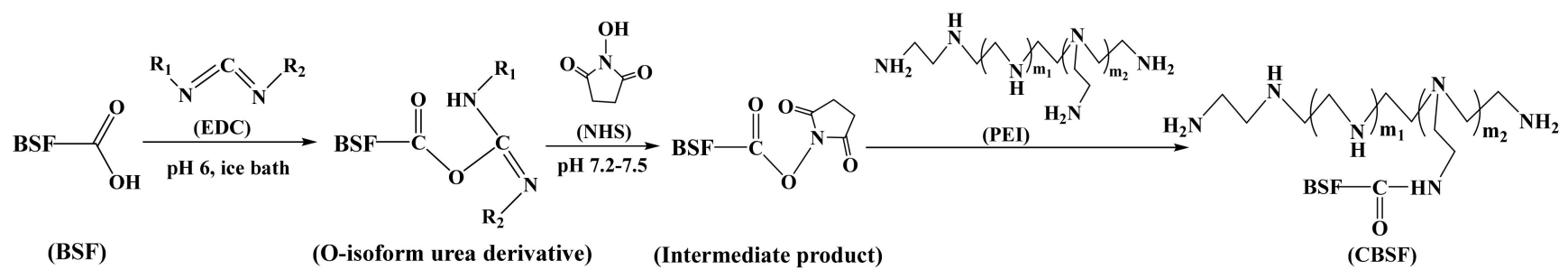

Figure 1. Schematic diagram of CBSF synthesis.

Figure 2A shows the zeta potential changes of the silk fibroin after reacting with different proportions of PEI. Under neutral conditions, the carboxyl groups on the side chains of aspartic acid and glutamic acid of silk fibroin easily lost $\mathrm{H}^{+}$and ionized into -COO-, causing the pure silk fibroin to become negatively charged and its zeta potential was approximately $-11.8 \pm 0.1 \mathrm{mV}$. When reacting with $0.1 \mathrm{wt} \% \mathrm{PEI}$, the zeta potential of silk fibroin turned from negative to positive, which was $+1.9 \pm 0.2 \mathrm{mV}$. With the increasing of PEI from $0.5 \mathrm{wt} \%$ to $4.0 \mathrm{wt} \%$, the zeta potentials increased from $+6.5 \pm 0.2 \mathrm{mV}$ to $+10.5 \pm 0.3 \mathrm{mV}$. When PEI accounting for $6.0 \%$ of the silk fibroin mass was added, the zeta potential of CBSF reached $+12.4 \pm 0.3 \mathrm{mV}$. As the mass ratios of PEI/BSF continued to increase, there was no significant increase in the zeta potential of CBSF.
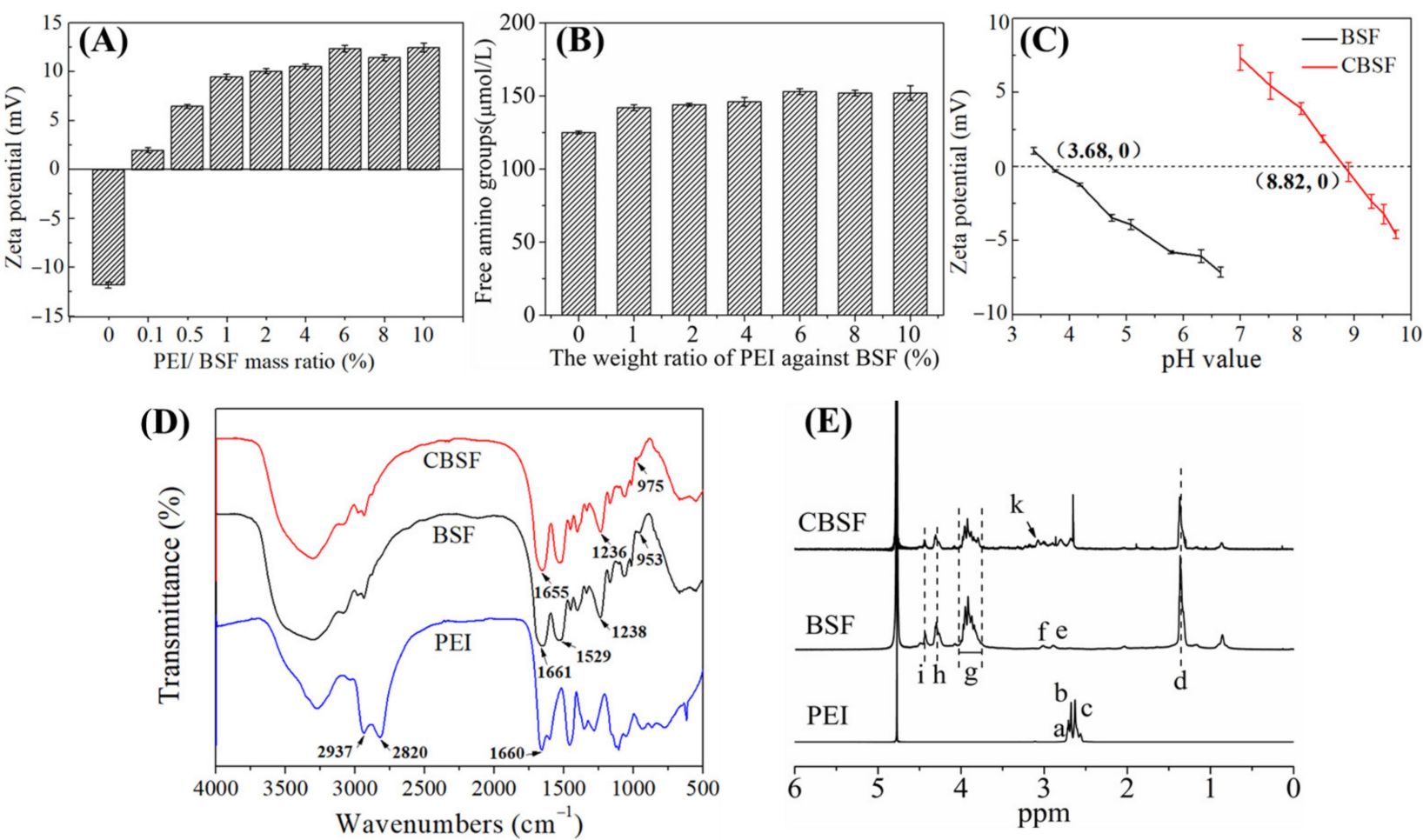

Figure 2. The characteristics of CBSF. (A) Zeta potentials of CBSF at different weight ratios of PEI with respect to BSF. (B) TNBS assay for the determination of free amino groups in PEI-modified BSF. (C) Isoelectric point values of BSF and CBSF (modified with $6.0 \mathrm{wt} \%$ PEI against BSF). (D) FTIR spectra of PEI, BSF, and CBSF. (E) ${ }^{1} \mathrm{H}-\mathrm{NMR}$ spectra of PEI, BSF, and CBSF. a: 2.71 ppm; b: 2.68 ppm; c: 2.62 ppm; d: 1.24 ppm; e: 2.78 ppm; f: 2.91 ppm; g: 3.63 3.91 ppm; h: 4.18 ppm; i: $\sim 4.32 \mathrm{ppm}$; $\mathrm{k}: \sim 3.12 \mathrm{ppm}$. Each value represents the mean $\pm \mathrm{SD}$ of three separate experiments $(\mathrm{n}=3$ per experiment).

The content of free amino groups in BSF modified by PEI is shown in Figure $2 \mathrm{~B}$. The content of free amino groups in unmodified BSF was $125.1 \pm 1.2 \mu \mathrm{mol} / \mathrm{mL}$. As the content of PEI increased from $1.0 \mathrm{wt} \%$ to $6.0 \mathrm{wt} \%$, the concentration of free amino groups in BSF increased from $142.6 \pm 2.4 \mu \mathrm{mol} / \mathrm{mL}$ to $153.5 \pm 2.2 \mu \mathrm{mol} / \mathrm{mL}$. However, there was no significant increase in free amino content after the addition of $8.0 \mathrm{wt} \%$ and $10.0 \mathrm{wt} \% \mathrm{PEI}$, 
indicating that BSF modified by $6.0 \mathrm{wt} \%$ PEI could maximize the concentration of free amino groups in the side chains.

The $\mathrm{pI}$ values of BSF and CBSF were measured by potentiometric titration at $\mathrm{pH} 3 \sim 10$, as shown in Figure 2C. The $\mathrm{pI}$ of the original BSF was approximately 3.68. After modification by $6.0 \mathrm{wt} \%$ PEI with respect to the weight of BSF, the pI of CBSF significantly increased to approximately 8.82 , suggesting that the negatively charged carboxyl groups in the side chains of BSF were consumed in the amidation reaction, exposing a large number of amino groups on the surface of BSF and changing the surface charge of BSF from negative to positive. The results demonstrated that BSF could be endowed effectively with a large amount of positive charge by modification with $6.0 \mathrm{wt} \%$ PEI.

The FTIR spectra of PEI, BSF, and CBSF are shown in Figure 2D. The absorptions at $2937 \mathrm{~cm}^{-1}$ and $2820 \mathrm{~cm}^{-1}$ represent the symmetrical and asymmetrical stretching vibration absorption of $-\mathrm{CH}_{2}$ in PEI, respectively. The in-plane bending vibration of the primary amino group $\left(-\mathrm{NH}_{2}\right)$ appeared at $1660 \mathrm{~cm}^{-1}$ [31,32]. The characteristic absorptions of BSF appeared at $1661 \mathrm{~cm}^{-1}(\mathrm{C}=\mathrm{O}$ stretching vibration, amide $\mathrm{I}), 1529 \mathrm{~cm}^{-1}(\mathrm{~N}-\mathrm{H}$ bending vibration and $\mathrm{C}-\mathrm{H}$ stretching vibration, amide II), and $1239 \mathrm{~cm}^{-1}(\mathrm{C}-\mathrm{N}$ stretching vibration and $\mathrm{N}-\mathrm{H}$ bending vibration, amide $\mathrm{III}$ ), and the absorption at $953 \mathrm{~cm}^{-1}$ represented the out of plane bending vibration of $\mathrm{O}-\mathrm{H}$ in carboxyl groups [33,34]. After the modification of BSF with PEI, the characteristic absorptions of BSF at $1661 \mathrm{~cm}^{-1}, 1238 \mathrm{~cm}^{-1}$, and $953 \mathrm{~cm}^{-1}$ shifted to $1655 \mathrm{~cm}^{-1}, 1236 \mathrm{~cm}^{-1}$, and $975 \mathrm{~cm}^{-1}$ in CBSF, respectively, suggesting that the $-\mathrm{COOH}$ on the side chain of BSF reacted with the $-\mathrm{NH}_{2}$ of PEI to form a new amide bond.

Figure $2 \mathrm{E}$ shows the ${ }^{1} \mathrm{H}-\mathrm{NMR}$ spectra of PEI, BSF, and CBSF. In the ${ }^{1} \mathrm{H}-\mathrm{NMR}$ spectra of PEI, $\delta$ 2.31 2.85 ppm (points a, b, and c) was the chemical shift corresponding to methylene protons in the $-\mathrm{NH}-\mathrm{CH}_{2}-\mathrm{CH}_{2}-$ group of the PEI monomer [35]. In the ${ }^{1} \mathrm{H}-\mathrm{NMR}$ spectra of BSF, the d point $(\delta \sim 1.24 \mathrm{ppm})$, e point $(\delta \sim 2.78 \mathrm{ppm})$, and $\mathrm{f}$ point $(\delta \sim 2.91 \mathrm{ppm})$ were the chemical shifts of the $-\mathrm{CH}-\mathrm{NH}_{2} \mathrm{CH}_{3}$ proton in Ala, $-\mathrm{CHNH}_{2}-\mathrm{CH}_{2}-$ proton in Tyr and $-\mathrm{CHNH}_{2}-\mathrm{CH}_{2}-$ proton in Asp, respectively, and the $\delta 3.63 \sim 3.91 \mathrm{ppm} g$ point was the chemical shift of the $\mathrm{NH}_{2}-\mathrm{CH}_{2}$ - proton in Gly and the $\mathrm{NH}_{2}-\mathrm{CH}_{2}-\mathrm{CH}$ - proton in Ser. The chemical shift of $-\mathrm{CH}-\mathrm{NH}_{2} \mathrm{CH}_{3}$ protons in Ala appeared at the $\mathrm{h}$ point $(\delta \sim 4.18 \mathrm{ppm})$ and $\delta \sim 4.32$ ppm at the i point was the chemical shift of the $-\mathrm{CH}-\mathrm{NH}_{2} \mathrm{OH}$ proton in Ser [36]. In the ${ }^{1} \mathrm{H}-\mathrm{NMR}$ spectrum of CBSF, a new proton peak appeared at the k point $(\delta \sim 3.12 \mathrm{ppm})$, which corresponded to the chemical shift of the methylene proton close to the amide bond in the $-\mathrm{CONHCH}_{2} \mathrm{CH}_{2} \mathrm{NH}$ - group [37], indicating that $-\mathrm{COOH}$ on the side chains of BSF reacted with the $-\mathrm{NH}_{2}$ of PEI to form an amide bond. The above results demonstrated that BSF was effectively modified by PEI. CASF obtained by modification of ASF with $6.0 \%$ PEI was used in subsequent experiments.

\subsection{Characterization of CBSF}

The negatively charged pDNA was packaged by positively charged CBSF via electrostatic interactions to form CBSF/pDNA complexes (Figure 3). Agarose gel electrophoresis was performed for CBSF/pDNA complexes at different mass ratios (Figure 4A) to assess the ability of CBSF to encapsulate pDNA. Marker (lane 1) and naked pDNA (lane 2) showed different fluorescent bands. When the mass ratios of CBSF/pDNA were 4/2,8/2, 16/2, and 32/2 (Lanes 3, 4, 5, and 6), clear fluorescent bands of pDNA could be seen in the figure, but the migration of pDNA was blocked, suggesting that CBSF could encapsulate pDNA. When the mass ratios of CBSF/pDNA were 64/2,128/2, 192/2, and 256/2 (lanes 7, 8, 9 , and 10), the migrations of pDNA were completely blocked, suggesting that when the mass ratios of CBSF to pDNA were greater than 64/2, CBSF could completely encapsulate and compress pDNA through electrostatic interactions. At this time, the blocking band of CBSF/pDNA was similar to that of 25kDa PEI/pDNA (lane 12), indicating that the encapsulation ability of CBSF to pDNA was similar to that of $25 \mathrm{kDa}$ PEI. 


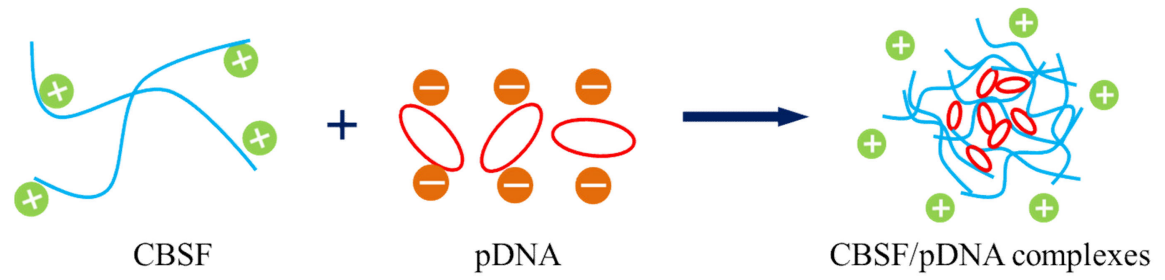

Figure 3. Schematic illustration of the formation of the CBSF/pDNA complexes.

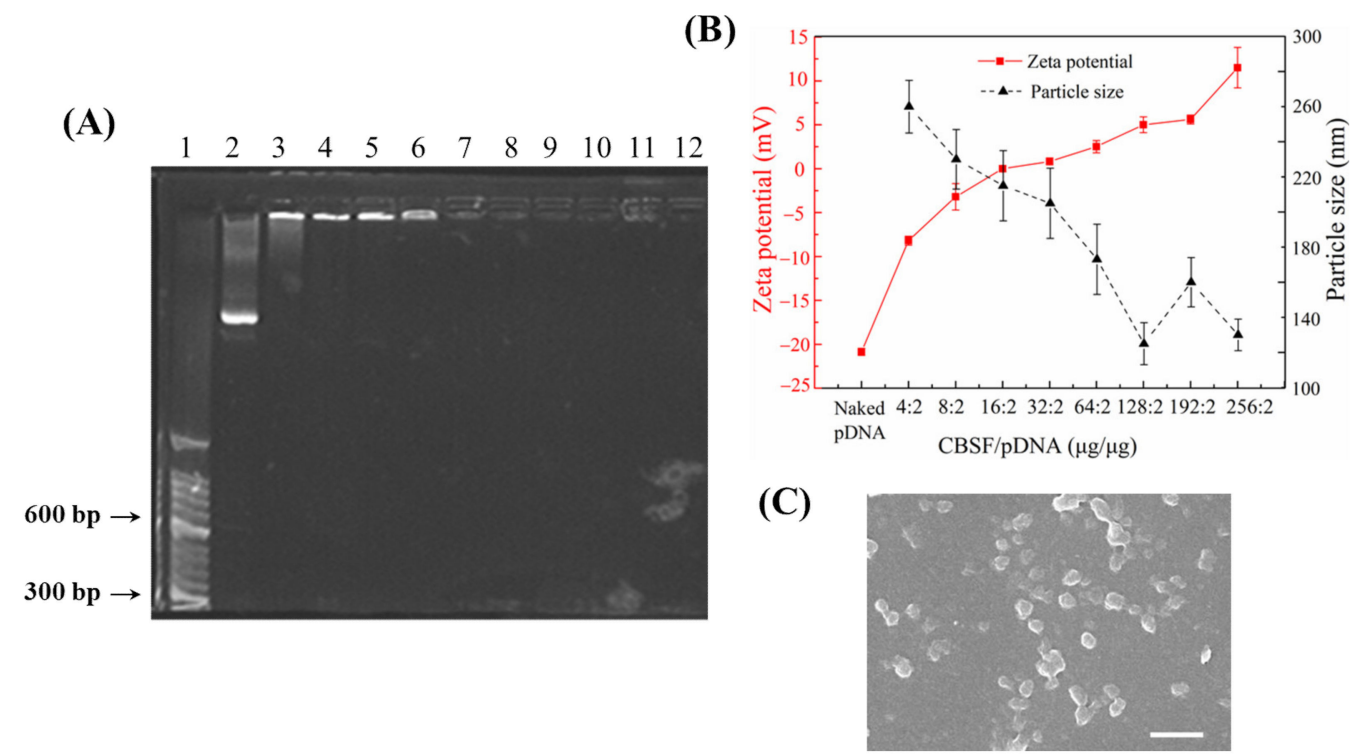

Figure 4. (A) Agarose gel electrophoresis of naked pDNA, CBSF/pDNA complexes and PEI/pDNA complexes. Lane 1: marker; lane 2: naked pDNA; lanes 3-10: CBSF/pDNA complexes at $w / w$ ratios of $4 / 2,8 / 2,16 / 2,32 / 2,64 / 2,128 / 2,196 / 2$, and 256/2; lane 11: $1.8 \mathrm{kDa} \mathrm{PEI} / \mathrm{pDNA}$ complex at a $w / w$ ratio of 10/3; lane 12: $25 \mathrm{kDa} \mathrm{PEI} / \mathrm{pDNA}$ complex at a $w / w$ ratio of 10/2. (B) Zeta potentials and particle sizes of complexes at different CBSF/pDNA weight ratios. (C) Scanning electron microscopy image of the CBSF/pDNA complex at a $w / w$ ratio of 256/2. Scale bar: $400 \mathrm{~nm}$.

Since the surface charges and sizes of the complexes would affect cell uptake to the complexes, the zeta potentials and particle sizes of CBSF/pDNA complexes at different mass ratios were tested [38], as shown in Figure 4B. The zeta potential of naked pDNA was $-20.9 \pm 0.4 \mathrm{mV}$. The zeta potential value of the CBSF/pDNA complex at a weight ratio of $4 / 2$ was $-8.2 \pm 0.5 \mathrm{mV}$, and the particle size was $\sim 260 \mathrm{~nm}$. As the mass ratio of CBSF / pDNA reached 32/2, the zeta potential of the complex reversed from negative to positive, which was $+0.8 \pm 0.4 \mathrm{mV}$, and the particle size decreased to $205 \mathrm{~nm}$. When the mass ratio of CBSF/pDNA increased from $64 / 2$ to $256 / 2$, the zeta potential increased from $+2.5 \pm 0.7 \mathrm{mV}$ to $+11.5 \pm 2.5 \mathrm{mV}$, and the particle size decreased from $\sim 170 \mathrm{~nm}$ to $\sim 120 \mathrm{~nm}$. The morphology of the CBSF/pDNA (256/2) complex was observed by SEM (Figure 4C). The pDNA was compressed and wrapped by CBSF to form a spherical complex with a diameter of approximately 100-200 nm (Figure 4C).

\subsection{In Vitro Transfection of A549 and WI-38 Cells with CBSF/pDNA Complexes}

A549 cells were transfected with different mass ratios of CBSF/pDNA complexes in vitro, and the expression of green fluorescent protein in cells and cell morphology were observed by CLSM, as shown in Figure 5A. The cells without the complexes did not show green fluorescence (Figure $5 \mathrm{~A}\left(\mathrm{a}_{1}\right)$ ). After the complex formed by $64 \mu \mathrm{g}$ of CBSF encapsulating $2 \mu \mathrm{g}$ of pDNA was cocultured with cells for $24 \mathrm{~h}$, the cells showed green fluorescence (Figure $\left.5 \mathrm{~A}\left(\mathrm{~b}_{1}\right)\right)$, indicating that the CBSF/pDNA complex could transfect A549 cells. When the $\mathrm{CBSF} / \mathrm{pDNA}$ mass ratio increased to $128 / 2$, the number of cells expressing green fluo- 
rescence increased and the fluorescence intensity increased (Figure $5 \mathrm{~A}\left(\mathrm{c}_{1}\right)$ ). However, when the ratio of CBSF/pDNA continued to increase to $256 / 2$ (Figure $5 \mathrm{~A}\left(\mathrm{~d}_{1}\right)$ ), the fluorescence intensity decreased, but it was similar to that of $25 \mathrm{kDa}$ PEI/pDNA (Figure $5 \mathrm{~A}\left(\mathrm{~d}_{1}, \mathrm{e}_{1}\right)$ ), indicating that the transfection efficiency of CBSF/pDNA (256/2) transfected A549 cells was similar to that of $25 \mathrm{kDa}$ PEI/pDNA (10/2). From the bright field figures, it can be seen that the untransfected A549 cells were evenly distributed with a fusiform shape (Figure 5A $\left(\mathrm{a}_{2}\right)$ ). When cells were cocultured with the CBSF/pDNA (64/2) complex for $24 \mathrm{~h}$, a few cells became round (Figure $5 \mathrm{~A}\left(\mathrm{~b}_{2}\right)$ ). When the ratios of CBSF/pDNA complexes increased to $128 / 2$ and $256 / 2$, most cells were rounded and partially aggregated (Figure $5 \mathrm{~A}\left(\mathrm{c}_{2}, \mathrm{~d}_{2}\right)$ ), indicating that the cell viability of A549 cells decreased. Compared with A549 cells transfected with the $25 \mathrm{kDa} / \mathrm{pDNA}(10 / 2)$ complex (Figure $5 \mathrm{~A}\left(\mathrm{e}_{2}\right)$ ), the circular cell density was higher after transfection with CBSF/pDNA complexes (128/2 and 256/2), showing that CBSF/pDNA (128/2 and 256/2) complexes had a stronger inhibitory effect on the proliferation of A549 cells.
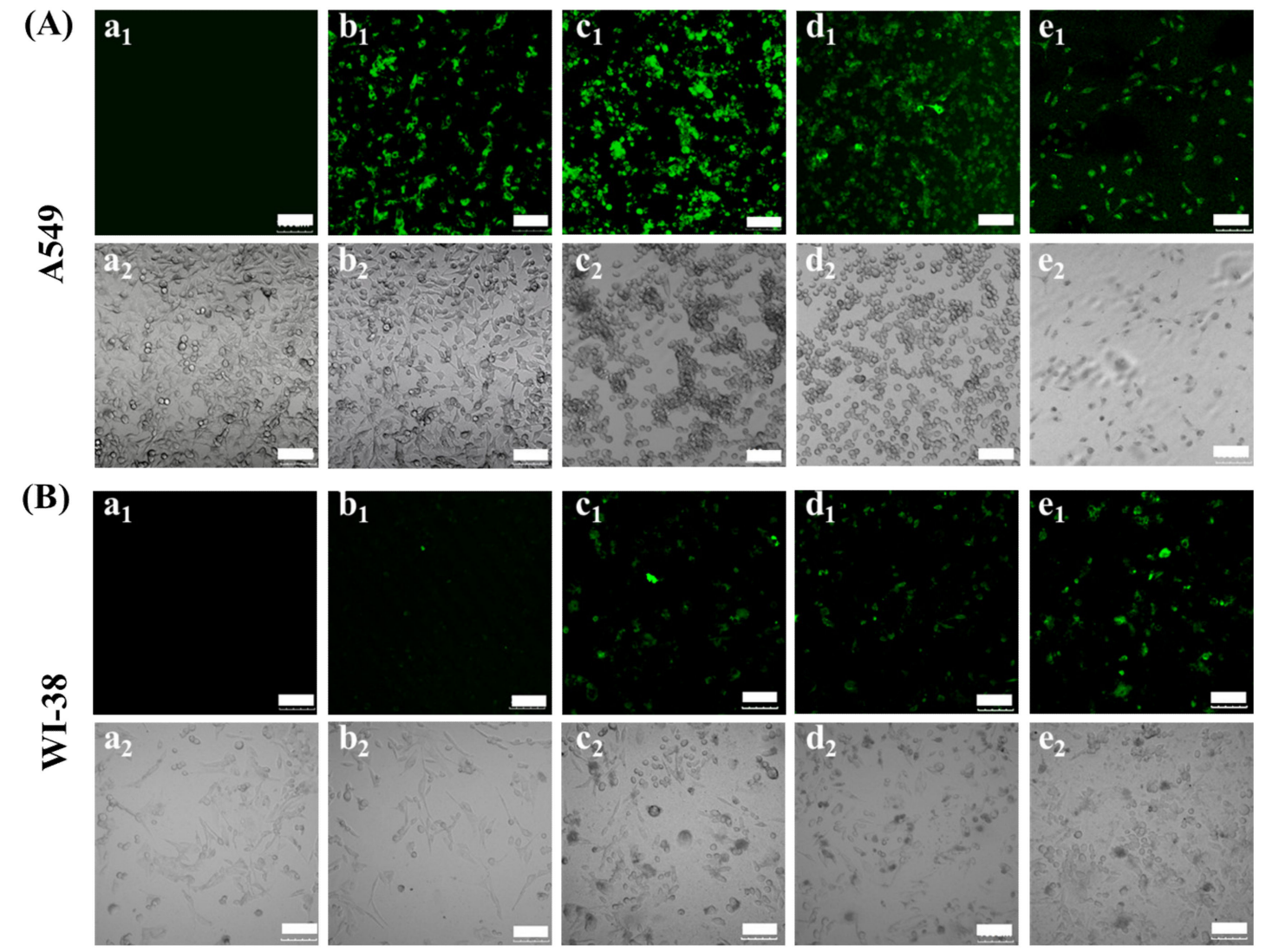

Figure 5. (A) Fluorescent micrographs of A549 cells transfected with different formulations. (B) Fluorescent micrographs of WI-38 cells transfected with different formulations. (a): Untreated cells; (b-d) represent CBSF/pDNA complexes with ratios of 64/2, 128/2, and 256/2, respectively; (e): A $25 \mathrm{kDa}$ PEI/pDNA complex at a $w / w$ ratio of 10/2. $\left(\mathbf{a}_{1}-\mathbf{e}_{1}\right)$ and (a. denote the fluorescent field and bright field, respectively. Scale bar: $50 \mu \mathrm{m}$.

WI-38 cells were selected for coculture with different mass ratios of CBSF/pDNA complexes for $24 \mathrm{~h}$. The CLSM images are shown in Figure 5B. Cells without complex coculture did not show green fluorescence (Figure $5 B\left(a_{1}\right)$ ). When WI-38 cells were cocultured with the CBSF/pDNA complex at a ratio of $64 / 2$, some cells showed weak green fluorescence (Figure $5 \mathrm{~B}\left(\mathrm{~b}_{1}\right)$ ). As the ratios of CBSF/pDNA increased to $128 / 2$ and 256/2, the number of cells expressing green fluorescence increased, and the fluorescence intensities were significantly enhanced (Figure $\left.5 B\left(c_{1}, d_{1}\right)\right)$, but lower than those of cells cocultured with the $25 \mathrm{kDa} / \mathrm{pDNA}(10 / 2)$ complex (Figure $5 \mathrm{~B}\left(\mathrm{e}_{1}\right)$ ). From the bright field diagram, the untransfected WI-38 cells were evenly distributed and fusiform (Figure $5 B\left(a_{2}\right)$ ). The 
addition of the CBSF/pDNA complex at a ratio of $64 / 2$ had no significant effect on cell morphology (Figure $5 \mathrm{~B}\left(\mathrm{~b}_{2}\right)$ ). When the ratios of CBSF/pDNA complexes were $128 / 2$ and 256/2, partial cells were still similar to the morphology of untransfected cells although local cells became round (Figure $5 \mathrm{~B}\left(\mathrm{c}_{2}, \mathrm{~d}_{2}\right)$ ), while most cells became round after adding $25 \mathrm{kDa} / \mathrm{pDNA}(10 / 2)$ complex to the WI-38 cells (Figure $5 \mathrm{~B}\left(\mathrm{e}_{2}\right)$ ). The results showed that CBSF as a gene carrier reduced cytotoxicity to normal cells compared with $25 \mathrm{kDa}$ PEI.

\subsection{Transfection Efficiency of Complexes Transfect A549 Cells}

Flow cytometry was used to detect the transfection efficiency after the A549 cells were cocultured with different mass ratios of complexes for $24 \mathrm{~h}$, as shown in Figure 6 . The cell transfection efficiency without complexes was $1.9 \%$. While the ratios of CBSF/pDNA complexes were $64 / 2,128 / 2$, and $256 / 2$, the transfection efficiencies of A549 cells were $24.1 \%$, $58.2 \%$, and $41.2 \%$, respectively, which were all higher than $11.2 \%$ of $25 \mathrm{kDa} \mathrm{PEI} / \mathrm{pDNA}$, indicating that CBSF/pDNA complexes could transfect A549 cells effectively and express green fluorescent proteins.
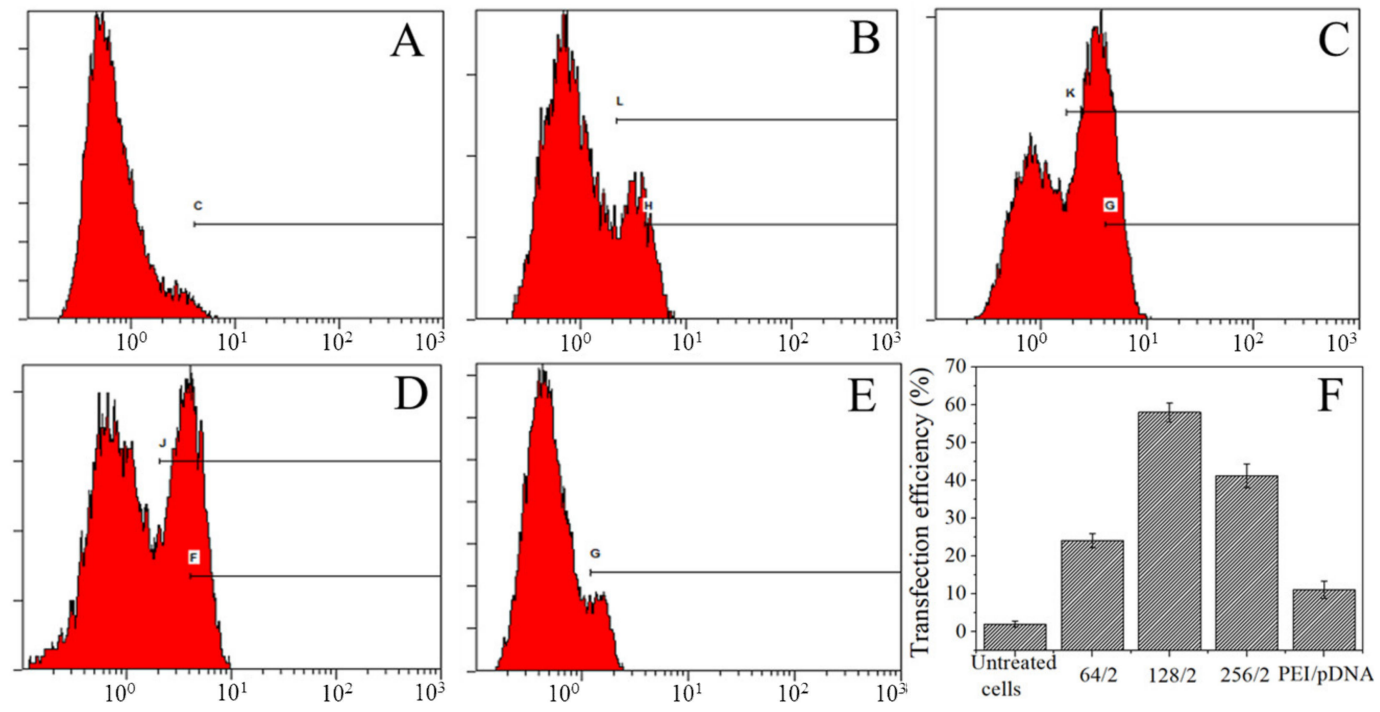

Figure 6. Transfection efficiency of A549 cells transfected with CBSF/pDNA complexes at different mass ratios for $24 \mathrm{~h}$. (A): untreated cells; (B-D) represent CBSF/pDNA complexes with ratios of 64/2, 128/2, and 256/2, respectively. (E): A $25 \mathrm{kDa}$ PEI/pDNA complex at a $w / w$ ratio of 10/2. (F): Transfection efficiency of two complexes at different mass ratios. Each value represents the mean $\pm \mathrm{SD}$ of three separate experiments.

\subsection{Effects of CBSF/pDNA Complexes on the Proliferation of A549 and WI-38 Cells}

As shown in Figure 7A, the cell viabilities of A549 cells and WI-38 cells transfected with different mass ratios of CBSF/pDNA complexes were measured by CCK- 8 assay. The cell viability of A549 cells cultured with naked pDNA and CBSF was $101.8 \pm 2.5$ and $100.9 \pm 4.0 \%$ respectively, indicating that pDNA and CBSF had no significant effects on the proliferation of A549 cells. After adding the CBSF/pDNA complexes at ratios of 64/2, $128 / 2$, and $256 / 2$, the cell viability decreased to $66.7 \pm 1.4 \%, 61.1 \pm 2.1 \%$, and $64.6 \pm 1.2 \%$, respectively, indicating that the addition of $\mathrm{CBSF} / \mathrm{pDNA}$ complexes could significantly inhibit A549 cell proliferation $(p<0.05)$. The cell viability after adding CBSF/pDNA complexes was lower than that after adding the $25 \mathrm{kDa} P E I / p D N A$ complex $(82.1 \pm 5.4 \%$, $p<0.05$ ), suggesting that the CBSF/pDNA complexes more significantly inhibited the proliferation of cancer cells compared with the $25 \mathrm{kDa}$ PEI/pDNA complex. 


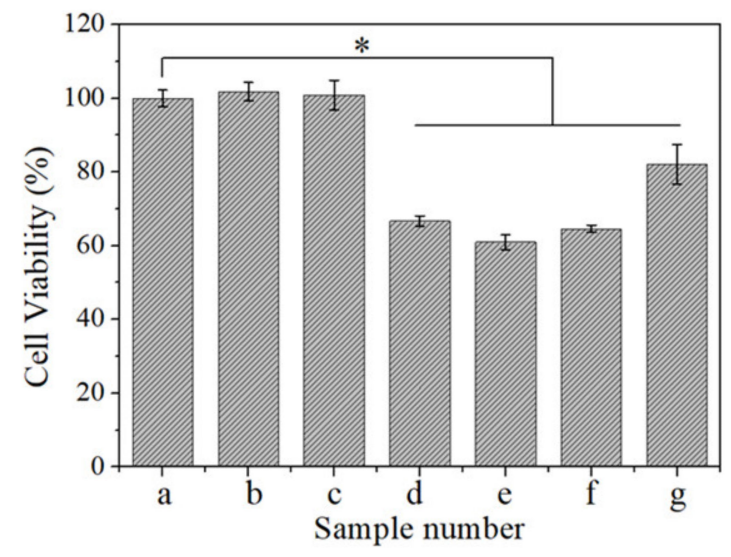

(A)

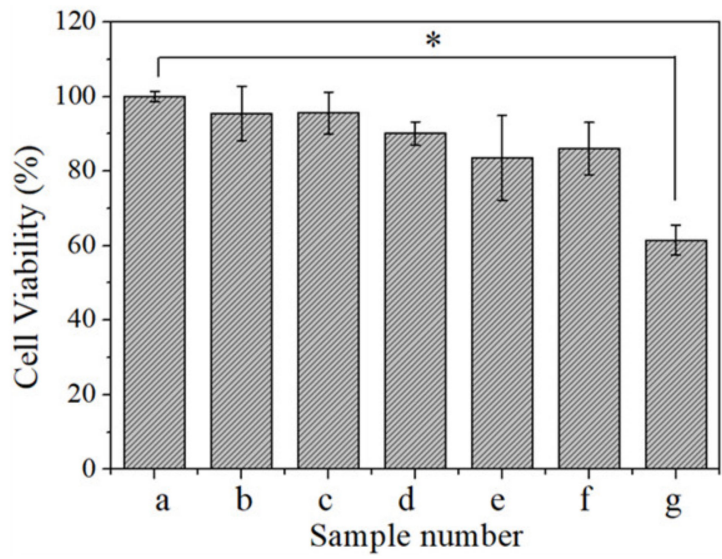

(B)

Figure 7. Viability of (A) A549 cells and (B) WI-38 cells after culturing with CBSF/pDNA complexes at predetermined weight ratios. a: Blank control; b: $2 \mu \mathrm{g}$ pDNA; c: $128 \mu \mathrm{g}$ CBSF; d-f: CBSF/pDNA complexes at $w / w$ ratios of 64/2, 128/2, and 256/2, respectively. g A $25 \mathrm{kDa}$ PEI/pDNA complex at a $w / w$ ratio of $10 / 2$. Each value represents the mean \pm SD of three separate experiments, $\mathrm{n}=3,{ }^{*} p<0.05$.

As shown in Figure 7B, when $2 \mu \mathrm{g}$ of pDNA and $128 \mu \mathrm{g}$ of CBSF were added, the cell viabilities of WI-38 cells were $95.5 \pm 7.3 \%$ and $95.6 \pm 5.6 \%$, respectively, indicating that pDNA and CBSF did not affect the proliferation of WI-38 cells. When the ratios of CBSF/pDNA complexes were $64 / 2,128 / 2$, and $256 / 2$, the cell viability decreased to $90.1 \pm 3.1 \%, 83.6 \pm 11.4 \%$, and $86.1 \pm 7.0 \%$, respectively. The values were higher than that of WI-38 cells transfected with the $25 \mathrm{kDa}$ PEI/pDNA complex $(61.5 \pm 4.2 \%, p<0.05)$, indicating that the CBSF/pDNA complexes showed lower cytotoxicity to normal cells than the $25 \mathrm{kDa}$ PEI/pDNA complexes.

\section{Discussion}

Efficient transfection with minimal associated cytotoxicity and safety concerns are the key qualities of gene carriers in cancer gene therapy. In non-viral gene vectors, high molecular weight polyethylenimine (PEI, $25 \mathrm{kDa}$ ) is considered the "gold" standard for gene delivery because of the proton sponge effect and the ability to protect DNA from degradation by enzymes $[15,27]$. However, its high charge density would cause severe cytotoxicity [39]. In contrast, PEI with a low-molecular-weight showed low cytotoxicity, but its transfection efficiency was limited [40]. To overcome the contradiction between transfection and toxicity, in this study, we attempted to graft low-molecular-weight PEI with Bombyx mori silk fibroin protein, in order to improve the transfection efficiency of low-molecular-weight PEI while giving it lower cytotoxicity.

The glutamic acid and aspartic acid in the side chains of BSF contain carboxyl groups, which could react with the carbon-nitrogen double bond $(-\mathrm{N}=\mathrm{C}-)$ in EDC to form $\mathrm{O}$ isourylurea derivatives. In the presence of NHS, they were converted into amino-active sulfonyl NHS esters. Then, the product reacted with the free amine group in PEI to form a stable amide bond, and finally CBSF was obtained (Figure 2A). During this reaction, the carboxyl groups of BSF were consumed, while the amino group content on the surface of CBSF increased. Therefore, as the amount of added PEI increased, the content of free amino groups of CBSF and the zeta potential increased at the beginning of the reaction (Figure $2 \mathrm{~A}, \mathrm{~B})$ ). When $6.0 \mathrm{wt} \%$ PEI was added, the amino group content increased to $153.5 \pm 2.2 \mu \mathrm{mol} / \mathrm{mL}$, and the zeta potential increased to $+12.4 \pm 0.3 \mathrm{mV}$. However, since the branched chain of PEI contained more protonated secondary amine and fulcrum amine groups, the carboxyl groups in BSF were quickly consumed. When the amount of added PEI was greater than $6.0 \mathrm{wt} \%$, the carboxyl groups on the side chains of BSF were almost completely consumed, so the free amino group content and zeta potential in CBSF did not change significantly at this time. Compared with the BSF solution, the CBSF solution 
modified with $6.0 \mathrm{wt} \%$ PEI had reduced carboxyl groups and increased amino group content, which increased the pI from 3.68 to 8.82 (Figure 2D). It can be observed from the FTIR spectrum of CBSF that the characteristic absorption of $\mathrm{C}=\mathrm{O}\left(1661 \mathrm{~cm}^{-1}\right), \mathrm{C}-\mathrm{N}$ $\left(1238 \mathrm{~cm}^{-1}\right)$, and O-H $\left(953 \mathrm{~cm}^{-1}\right)$ in BSF were shifted to $1655 \mathrm{~cm}^{-1}, 1236 \mathrm{~cm}^{-1}$, and $975 \mathrm{~cm}^{-1}$, respectively (Figure 2D). The changes could be attributed to the $\mathrm{O}=\mathrm{C}-\mathrm{N}$ in-plane bending vibration, which was caused by the reaction between $-\mathrm{COOH}$ in the side chains of $\mathrm{BSF}$ and $-\mathrm{NH}_{2}$ in PEI [27]. In addition, in the ${ }^{1} \mathrm{H}-\mathrm{NMR}$ spectrum, the methylene proton peak at $\delta \sim 3.12 \mathrm{ppm}$ corresponded to the formation of a new amide bond (Figure 2E). The above results indicated that PEI was grafted onto the side chains of BSF.

One key aspect of gene delivery is the packaging of genetic material into structures which can be efficiently transported into cells [41]. Therefore, the ability of non-viral vectors to bind nucleic acids is a prerequisite for gene delivery. Negatively charged BSF in solution was not able to encapsulate the negatively charged pDNA because of charge repulsion, so the migration of pDNA still occurred (Figure 4A, lane 2). BSF modified by PEI was positively charged and could encapsulate pDNA via electrostatic interactions to form CBSF/pDNA complexes (Figure 3). When the ratios of CBSF/pDNA were greater than $64 / 2$, the encapsulation effect of CBSF on pDNA was similar to that of $25 \mathrm{kDa}$ PEI (Figure $4 \mathrm{~A}$ ) and the zeta potentials of the complexes reversed to positive values (Figure 4B). The positive charge of the complexes can help to bind to the surface of the anionic cells and promote cell uptake of the complexes, thus improving the transfection efficiency [42]. However, cell uptake is also closely related to the size of the complexes [43]. In this study, CBSF could encapsulate pDNA into compact spherical CBSF/pDNA (256/2) complexes with a diameter of approximately 100-200 nm (Figure 4C) and nanoparticles of this size can be endocytosed by the cells [44].

In order to evaluate the transfection effectiveness of the CBSF/pDNA complexes in cancer cells and normal cells, CBSF/pDNA complexes with mass ratios of 64/2, 128/2, and 256/2 were cocultured with A549 and WI-38 cells. The 64/2 CBSF/pDNA complex showed a positive zeta potential (Figure $4 \mathrm{~B}$ ), it could adhere to the negatively charged A549 cell membrane surface through electrostatic interactions, and be further internalized by the cells for effective transfection, with a transfection efficiency of $24.1 \%$ (Figure $6 \mathrm{~b}$ ). Meanwhile, there was obvious expression of GFP in A549 cells (Figure 5A $\left(\mathrm{b}_{1}\right)$ ). Compared with the $64 / 2 \mathrm{CBSF} / \mathrm{pDNA}$ complex, the 128/2 CBSF/pDNA complex had more positive charges (Figure $4 \mathrm{~B}$ ) and showed stronger adhesion to the cell membrane, resulting in the transfection efficiency significantly increasing to $58.2 \%$ (Figure $6 \mathrm{C}$ ) and the expression of GFP being enhanced (Figure $5 A\left(c_{1}\right)$ ). In contrast, the transfection efficiency of the 256/2 CBSF/pDNA complex on A549 cells was reduced (Figure 6D), which may be because CBSF with a high mass ratio can form a strong condensation ability with pDNA, which made it difficult for cells to release pDNA from the complex after ingestion, leading to a reduced transfection efficiency [45]. Importantly, the transfection efficiency of the above proportions of CBSF/pDNA complexes was higher than that of $25 \mathrm{kDa}$ PEI/pDNA $11.05 \%$ (Figure 6E), indicating that CBSF had a higher transfection efficiency to cancer cells than $25 \mathrm{kDa}$ PEI. Moreover, the ING4-IL-24 double gene can inhibit the proliferation of cancer cells intracellularly and extracellularly [9]. The number of round A549 cells in the field of vision increased (Figure $5 \mathrm{~A}\left(\mathrm{~b}_{2}-\mathrm{d}_{2}\right)$ ) and the cell viability of the A549 cells significantly decreased (Figure 7A) as the mass ratios of CBSF/pDNA increased. If CBSF was modified by ligands that specifically identify lung cancer cells (e.g., transferrin, transformation factor $\alpha$, hyaluronic acid, folic acid, and peptides) and used to package pDNA, the complex is expected to further inhibit the proliferation of cancer cells [46,47]. These results suggested that CBSF, as a gene carrier, could effectively deliver the ING4-IL-24 double gene, thereby inhibiting the proliferation of A549 cells. For normal WI-38 cells, the CBSF/pDNA complexes could be transfected into cells, but showed lower GFP expression than cancer cells (Figure $\left.5 B\left(b_{1}-d_{1}\right)\right)$. This may be due to the fact that normal cells express different numbers of receptors on the surface of the cell membrane compared to cancer cells, which may affect the available binding sites to the complexes and the uptake of the complexes [28]. Different 
transfection efficiencies and GFP expression of the same gene vector in different cell lines have also been found in other studies [48]. These results illustrated that CBSF/pDNA complexes could effectively transfect A549 cells, reaching thetransfection efficiency higher than that of $25 \mathrm{kDa} \mathrm{PEI} / \mathrm{pDNA}$ complexes, and inhibiting the proliferation of A549 cells.

Cytotoxicity is an important factor in evaluating the application of vectors in gene delivery. The cell morphology of WI-38 cells cocultured with the CBSF/pDNA complexes was similar to that of untransfected cells (Figure $5 \mathrm{~B}\left(\mathrm{a}_{1}-\mathrm{d}_{1}\right)$ ), with cell viability maintained at over $80 \%$ (Figure $7 \mathrm{~B}$ ). However, cells cocultured with $25 \mathrm{kDa}$ PEI/pDNA were almost round (Figure $5 \mathrm{~B}\left(\mathrm{e}_{1}\right)$ ), and cell viability was significantly decreased (Figure $7 \mathrm{~B}$ ). It is mainly due to the zeta potential of CBSF/pDNA complex being lower than 25kDa PEI/pDNA complex $[27,49]$. Therefore, compared with 25kDa PEI/pDNA, CBSF/pDNA significantly reduced the cytotoxicity to normal lung WI-38 cells. In our study, it can be observed that the $\mathrm{CBSF} / \mathrm{pDNA}$ complex showed selective cytotoxicity and that the proliferation of A549 cells was significantly inhibited but there was no significant effect on WI-38 cells (Figure 7A,B). This might be derived from the expression of IL-24. A study showed that IL-24 inhibited the expression of the transcription factor GLI1, which is overexpressed in lung cancer cells, by inhibiting the Akt-mTOR and SDF-1/CXCR4 signaling axes, thereby inducing DNA damage in lung cancer cells and leading to cell death, however, the protein expression of GLI1 in normal cells did not change significantly [7]. Although the uptake of the complexes by cells has been identified, the expression of the ING4-IL-24 double gene after transfection of the complexes and the inhibitory effect on tumor cells still needs to be further explored. The results of this paper show that CBSF, as a gene carrier, can encapsulate the ING4-IL-24 double gene and further effectively transfect lung cancer A549 cells and significantly inhibit the proliferation of A549 cells, but has no obvious toxicity to normal WI-38 cells.

\section{Conclusions}

In this study, BSF was modified with low-molecular-weight (1.8 kDa) PEI. The obtained CBSF could encapsulate double gene coexpression plasmid DNA encoded by ING4 and IL-24 to form CBSF/pDNA complexes. The complexes were transfected into human lung adenocarcinoma cells A549 and human embryonic lung fibroblasts WI-38 in vitro. Zeta potentials, isoelectric points, the content of free amino groups, FTIR and ${ }^{1} \mathrm{H}-\mathrm{NMR}$ results showed that the amino groups in PEI reacted effectively with the carboxyl groups on the side chains of BSF, which made the surface charges of BSF change from negative to positive. Based on the electrostatic interaction, CBSF can package pDNA to form nanoscale spherical particles. When CBSF/pDNA complexes were transfected into A549 cells in vitro, the transfection efficiencies were higher than that of the $25 \mathrm{kDa} P E I / p D N A$ complexes. In particular, the transfection efficiency reached approximately 58.2\% when the CBSF/pDNA ratio of the complex was 128/2, which significantly inhibited the proliferation of A549 cells, and importantly, there was no significant change in WI-38 cell proliferation, and the toxicity of CBSF to WI-38 cells was significantly lower than that of $25 \mathrm{kDa}$ PEI. CBSF may be used as a new gene carrier in clinical gene therapy.

Author Contributions: Conceptualization, L.N., G.C. and M.L.; methodology, L.N., G.C., Y.F., P.P., L.H. and Y.G.; software, G.C. and X.L.; validation, Y.F., G.C. and M.L.; formal analysis, G.C., Y.F. and X.L.; investigation, L.N., G.C., X.L., Y.F., P.P., L.H. and Y.G.; resources, M.L.; data curation, L.N., P.P., L.H. and Y.G.; writing—original draft preparation, L.N. and G.C.; writing—review and editing, M.L.; visualization, X.L.; supervision, X.L.; project administration, M.L.; funding acquisition, M.L. All authors have read and agreed to the published version of the manuscript.

Funding: This work was supported by the National Key Research and Development Program of China (Project No. 2017YFC1103602, 2017YFC1103603).

Institutional Review Board Statement: Not applicable.

Informed Consent Statement: Not applicable.

Data Availability Statement: Data is contained within the article. 
Acknowledgments: The authors gratefully acknowledge Jicheng Yang and Weihua Sheng from College of Medicine in Soochow University for technical assistance.

Conflicts of Interest: The authors declare no conflict of interest.

\section{References}

1. Laksee, S.; Supachettapun, C.; Muangsin, N.; Lertsarawut, P.; Rattanawongwiboon, T.; Sricharoen, P.; Limchoowong, N.; Chutimasakul, T.; Kwamman, T.; Hemvichian, K. Targeted gold nanohybrids functionalized with folate-hydrophobic-quaternized pullulan delivering camptothecin for enhancing hydrophobic anticancer drug efficacy. Polymers 2021, 13, 2670. [CrossRef]

2. Engel, J.; Lategahn, J.; Rauh, D. Hope and disappointment: Covalent inhibitors to overcome drug resistance in non-small cell lung cancer. ACS Med. Chem. Lett. 2016, 7, 2-5. [CrossRef]

3. Lee, H.; Mohammed, K.A.; Nasreen, N. Nanoparticle-based targeted gene therapy for lung cancer. Nanoparticles Lung Cancer 2016, $6,1118-1134$.

4. Xu, M.; Xie, Y.; Sheng, W.; Miao, J.; Yang, J. Adenovirus-mediated ING4 gene transfer in osteosarcoma suppresses tumor growth via induction of apoptosis and inhibition of tumor angiogenesis. Technol. Cancer Res. Treat. 2014, 14, 369-378. [CrossRef] [PubMed]

5. Nozell, S.; Laver, T.; Moseley, D.; Nowoslawski, L.; De Vos, M.; Atkinson, G.P.; Harrison, K.; Nabors, L.B.; Benveniste, E.N. The ING4 tumor suppressor attenuates NF-kB activity at the promoters of target genes. Mol. Cell Biol. 2008, 28, 6632-6645. [CrossRef] [PubMed]

6. Li, M.; Zhu, Y.; Zhang, H.; Li, L.; He, P.; Xia, H.; Zhang, Y.; Mao, C. Delivery of inhibitor of growth 4 (ING4) gene significantly inhibits proliferation and invasion and promotes apoptosis of human osteosarcoma cells. Sci. Rep. 2014, 4, 7380-7389. [CrossRef]

7. Panneerselvam, J.; Srivastava, A.; Mehta, M.; Chen, A.; Zhao, Y.D.; Munshi, A.; Ramesh, R. IL-24 inhibits lung cancer growth by suppressing GLI1 and inducing DNA damage. Cancers 2019, 11, 1879. [CrossRef]

8. Su, Z.; Emdad, L.; Sauane, M.; Lebedeva, I.V.; Sarkar, D.; Gupta, P.; James, C.D.; Randolph, A.; Valerie, K.; Walter, M.R.; et al Unique aspects of mda-7/IL-24 antitumor bystander activity: Establishing a role for secretion of MDA-7/IL-24 protein by normal cells. Oncogene 2005, 24, 7552-7566. [CrossRef]

9. Qu, J.; Wang, W.; Feng, Y.; Niu, L.; Li, M.; Yang, J.; Xie, Y. Cationic antheraea pernyi silk fibroin-modified adenovirus-mediated ING4 and IL-24 dual gene coexpression vector suppresses the growth of hepatoma carcinoma cells. Int. J. Nanomed. 2019, 14, 9745-9761. [CrossRef]

10. Kuzmich, A.; Rakitina, O.; Didych, D.; Potapov, V.; Zinovyeva, M.; Alekseenko, I.; Sverdlov, E. Novel histone-based DNA carrier targeting cancer-associated fibroblasts. Polymers 2020, 12, 1695. [CrossRef]

11. Santana-Armas, M.L.; Tros de Ilarduya, C. Strategies for cancer gene-delivery improvement by non-viral vectors. Int. J. Pharm. 2021, 596, 120291-120299. [CrossRef] [PubMed]

12. Wahane, A.; Waghmode, A.; Kapphahn, A.; Dhuri, K.; Gupta, A.; Bahal, R. Role of lipid-based and polymer-based non-viral vectors in nucleic acid delivery for next-generation gene therapy. Molecules 2020, 25, 2866. [CrossRef] [PubMed]

13. Yu, Q.Y.; Zhan, Y.R.; Zhang, J.; Luan, C.R.; Wang, B.; Yu, X.Q. Aromatic modification of low molecular weight PEI for enhanced gene delivery. Polymers 2017, 9, 362. [CrossRef] [PubMed]

14. Babaei, M.; Eshghi, H.; Abnous, K.; Rahimizadeh, M.; Ramezani, M. Promising gene delivery system based on polyethyleniminemodified silica nanoparticles. Cancer Gene Ther. 2017, 24, 156-164. [CrossRef] [PubMed]

15. Wang, J.; Li, S.; Chen, T.; Xian, W.; Zhang, H.; Wu, L.; Zhu, W.; Zeng, Q. Nanoscale cationic micelles of amphiphilic copolymers based on star-shaped PLGA and PEI cross-linked PEG for protein delivery application. J. Mater. Sci. Mater. Med. 2019, 30, 93-106. [CrossRef] [PubMed]

16. Li, Q.; Hao, X.; Wang, H.; Guo, J.; Ren, X.K.; Xia, S.; Zhang, W.; Feng, Y. Multifunctional REDV-G-TAT-G-NLS-Cys peptide sequence conjugated gene carriers to enhance gene transfection efficiency in endothelial cells. Colloids Surf. B Biointerfaces 2019, 184, 110510-110520. [CrossRef]

17. Kuo, W.T.; Huang, H.Y.; Chou, M.J.; Wu, M.C.; Huang, Y.Y. Surface modification of gelatin nanoparticles with polyethylenimine as gene vector. J. Nanomater. 2011, 2011, 1-5. [CrossRef]

18. Zhang, J.; Song, J.; Liang, X.; Yin, Y.; Zuo, T.; Chen, D.; Shen, Q. Hyaluronic acid-modified cationic nanoparticles overcome enzyme CYP1B1-mediated breast cancer multidrug resistance. Nanomedicine 2019, 14, 447-464. [CrossRef]

19. Clima, L.; Craciun, B.F.; Gavril, G.; Pinteala, M. Tunable composition of dynamic non-viral vectors over the DNA polyplex formation and nucleic acid transfection. Polymers 2019, 11, 1313. [CrossRef]

20. Sharmeen, S.; Rahman, A.M.; Lubna, M.M.; Salem, K.S.; Islam, R.; Khan, M.A. Polyethylene glycol functionalized carbon nanotubes/gelatin-chitosan nanocomposite: An approach for significant drug release. Bioact. Mater. 2018, 3, 236-244. [CrossRef] [PubMed]

21. Yang, W.; Xu, H.; Lan, Y.; Zhu, Q.; Liu, Y.; Huang, S.; Shi, S.; Hancharou, A.; Tang, B.; Guo, R. Preparation and characterisation of a novel silk fibroin/hyaluronic acid/sodium alginate scaffold for skin repair. Int. J. Biol. Macromol. 2019, 130, 58-67. [CrossRef]

22. Chen, Z.; Zhang, Q.; Li, H.; Wei, Q.; Zhao, X.; Chen, F. Elastin-like polypeptide modified silk fibroin porous scaffold promotes osteochondral repair. Bioact. Mater. 2021, 6, 589-601. [CrossRef] [PubMed]

23. Norouzi, P.; Motasadizadeh, H.; Atyabi, F.; Dinarvand, R.; Gholami, M.; Farokhi, M.; Shokrgozar, M.A.; Mottaghitalab, F. Combination therapy of breast cancer by codelivery of doxorubicin and survivin siRNA using polyethylenimine modified silk fibroin nanoparticles. ACS Biomater. Sci. Eng. 2021, 7, 1074-1087. [CrossRef] [PubMed] 
24. Tomeh, M.A.; Hadianamrei, R.; Zhao, X. Silk fibroin as a functional biomaterial for drug and gene delivery. Pharmaceutics 2019, 11, 494. [CrossRef] [PubMed]

25. Liu, Y.; Zheng, Z.; Gong, H.; Liu, M.; Guo, S.; Li, G.; Wang, X.; Kaplan, D.L. DNA preservation in silk. Biomater. Sci. 2017, 5, 1279-1292. [CrossRef]

26. Farokhi, M.; Mottaghitalab, F.; Reis, R.L.; Ramakrishna, S.; Kundu, S.C. Functionalized silk fibroin nanofibers as drug carriers: Advantages and challenges. J. Control Release 2020, 321, 324-347. [CrossRef]

27. Luo, Z.; Li, J.; Qu, J.; Sheng, W.; Yang, J.; Li, M. Cationized bombyx mori silk fibroin as a delivery carrier of the VEGF165-Ang-1 coexpression plasmid for dermal tissue regeneration. J. Mater. Chem. B 2019, 7, 80-94. [CrossRef]

28. Niu, L.; Shi, M.; Feng, Y.; Sun, X.; Wang, Y.; Cheng, Z.; Li, M. The interactions of quantum dot-labeled silk fibroin micro/nanoparticles with cells. Materials 2020, 13, 3372. [CrossRef]

29. Kajiwara, S.; Komatsu, K.; Yamada, R.; Matsumoto, T.; Yasuda, M.; Ogino, H. Improvement of the organic solvent stability of a commercial lipase by chemical modification with dextran. Biochem. Eng. J. 2019, 142, 1-6. [CrossRef]

30. Xie, Y.; Lv, H.; Sheng, W.; Miao, J.; Xiang, J.; Yang, J. Synergistic tumor suppression by adenovirus-mediated inhibitor of growth 4 and interleukin-24 gene cotransfer in hepatocarcinoma cells. Cancer Biother. Radiopharm. 2011, 26, 681-695. [CrossRef]

31. Liu, H.; Li, K.; Xu, L.; Wu, D. Bilayered near-infrared fluorescent nanoparticles based on low molecular weight PEI for tumortargeted in vivo imaging. J. Nanopart. Res. 2014, 16, 2784-2795. [CrossRef]

32. Dong, H.; Ding, L.; Yan, F.; Ji, H.; Ju, H. The use of polyethylenimine-grafted graphene nanoribbon for cellular delivery of locked nucleic acid modified molecular beacon for recognition of microRNA. Biomaterials 2011, 32, 3875-3882. [CrossRef]

33. Byram, P.K.; Sunka, K.C.; Barik, A.; Kaushal, M.; Dhara, S.; Chakravorty, N. Biomimetic silk fibroin and xanthan gum blended hydrogels for connective tissue regeneration. Int. J. Biol. Macromol. 2020, 165, 874-882. [CrossRef]

34. Shao, J.; Zheng, J.; Liu, J.; Carr, C.M. Fourier transform Raman and Fourier transform infrared spectroscopy studies of silk fibroin. J. Appl. Polym. Sci. 2005, 96, 1999-2004. [CrossRef]

35. Nurhasni, H.; Cao, J.; Choi, M.; Kim, I.; Lee, B.L.; Jung, Y.; Yoo, J.W. Nitric oxide-releasing poly (lactic-co-glycolic acid)polyethylenimine nanoparticles for prolonged nitric oxide release, antibacterial efficacy, and in vivo wound healing activity. Int. J. Nanomed. 2015, 10, 3065-3080.

36. Zainuddin; Le, T.T.; Park, Y.; Chirila, T.V.; Halley, P.J.; Whittaker, A.K. The behavior of aged regenerated Bombyx mori silk fibroin solutions studied by ${ }^{1} \mathrm{H}$ NMR and rheology. Biomaterials 2008, 29, 4268-4274. [CrossRef] [PubMed]

37. Ping, Y.; Hu, Q.; Tang, G.; Li, J. FGFR-targeted gene delivery mediated by supramolecular assembly between $\beta$-cyclodextrincrosslinked PEI and redox-sensitive PEG. Biomaterials 2013, 34, 6482-6494. [CrossRef]

38. Guo, S.; Liang, Y.; Liu, L.; Yin, M.; Wang, A.; Sun, K.; Li, Y.; Shi, Y. Research on the fate of polymeric nanoparticles in the process of the intestinal absorption based on model nanoparticles with various characteristics: Size, surface charge and pro-hydrophobics. J. Nanobiotechnol. 2021, 19, 32-52. [CrossRef] [PubMed]

39. Ullah, I.; Zhao, J.; Su, B.; Rukh, S.; Guo, J.; Ren, X.K.; Xia, S.; Zhang, W.; Feng, Y. Redox stimulus disulfide conjugated polyethyleneimine as a shuttle for gene transfer. J. Mater. Sci. Mater. Med. 2020, 31, 118-129. [CrossRef] [PubMed]

40. Wu, X.R.; Zhang, J.; Zhang, J.H.; Xiao, Y.P.; He, X.; Liu, Y.H.; Yu, X.Q. Amino acid-linked low molecular weight polyethylenimine for Improved gene delivery and biocompatibility. Molecules 2020, 25, 975. [CrossRef]

41. Syga, M.I.; Nicoli, E.; Kohler, E.; Shastri, V.P. Albumin incorporation in polyethylenimine-DNA polyplexes influences transfection efficiency. Biomacromolecules 2016, 17, 200-207. [CrossRef] [PubMed]

42. Forest, V.; Pourchez, J. Preferential binding of positive nanoparticles on cell membranes is due to electrostatic interactions: A too simplistic explanation that does not take into account the nanoparticle protein corona. Mater. Sci. Eng. C 2017, 70, 889-896. [CrossRef] [PubMed]

43. Wu, M.; Guo, H.; Liu, L.; Liu, Y.; Xie, L. Size-dependent cellular uptake and localization profiles of silver nanoparticles. Int. J. Nanomed. 2019, 14, 4247-4259. [CrossRef]

44. Han, J.; Wang, Q.; Zhang, Z.; Gong, T.; Sun, X. Cationic bovine serum albumin based self-assembled nanoparticles as siRNA delivery vector for treating lung metastatic cancer. Small 2014, 10, 524-535. [CrossRef]

45. Wu, D.; Zhang, Y.; Xu, X.; Guo, T.; Xie, D.; Zhu, R.; Chen, S.; Ramakrishna, S.; He, L. RGD/TAT-functionalized chitosan-graft-PEIPEG gene nanovector for sustained delivery of NT-3 for potential application in neural regeneration. Acta Biomater. 2018, 72, 266-277. [CrossRef] [PubMed]

46. Pang, J.; Xing, H.; Sun, Y.; Feng, S.; Wang, S. Non-small cell lung cancer combination therapy: Hyaluronic acid modified, epidermal growth factor receptor targeted, $\mathrm{pH}$ sensitive lipid-polymer hybrid nanoparticles for the delivery of erlotinib plus bevacizumab. Biomed. Pharmacother. 2020, 125, 109861. [CrossRef]

47. Tan, S.; Wang, G. Lung cancer targeted therapy: Folate and transferrin dual targeted, glutathione responsive nanocarriers for the delivery of cisplatin. Biomed Pharmacother. 2018, 102, 55-63. [CrossRef]

48. Kunath, K. Low-molecular-weight polyethylenimine as a non-viral vector for DNA delivery: Comparison of physicochemical properties, transfection efficiency and in vivo distribution with high-molecular-weight polyethylenimine. J. Control Release 2003, 89, 113-125. [CrossRef]

49. Tian, H.; Lin, L.; Jiao, Z.; Guo, Z.; Chen, J.; Gao, S.; Zhu, X.; Chen, X. Polylysine-modified polyethylenimine inducing tumor apoptosis as an efficient gene carrier. J. Control Release 2013, 172, 410-418. [CrossRef] 